\title{
Välitööd rahvuskaaslaste juures Krasnojarski krais
}

\begin{abstract}
Anu Korb
Rahvaloenduse andmetel elas 2002. aastal Krasnojarski krais veel umbes 4000 eestlast, linnas neist umbes tuhat. Eestis teatakse enim 19. sajandil Vene tsaari poolt väljasaadetute rajatud külasid Ülem-Suetuk (vene k Верхний Суэтук) ja Ülem-Bulanka (Верхняя Буланка). Rida Krasnojarski kraisse jäävaid külasid tekkis aga 19. sajandi lõpukümnendil ja 20. sajandi algul vaba maa otsingul väljarännanuist. Siberis elab ka küüditatute järglasi, Teise maailmasõja järel paremate töövõimaluste otsingul Siberisse jäänuid jt.

Mullusuviselt ekspeditsioonilt naasnuna hakkasin kohe kavandama uut kogumisreisi, sest Krasnojarski krai setu kogukonnad osutusid üle ootuste pärimusrikkaks (vt Korb 2007). Selgus, et üksnes Haida külas (vene k Haidak) võiks töötada terve kuu või rohkemgi, ning mitmesse piirkonna külasse me ei jõudnudki.

Välitööde õnnestumises on oluline hea meeskond. Andreas Kalkun, kes mullu käis Siberis esmakordselt, tahtis jätkata. Astrid Tuisk, kel jäi toonase pronkssõduri-mässu tõttu sõitmata, plaanis nüüd kindlasti osaleda. Kui otsustasime, et seekordne välitöörühm võiks olla nelja-liikmeline, liitus meiega Andrease soovitusel Tiit Sibul Eesti Rahva Muuseumist.

Siberi-reisi jätsime augustikuusse, sest juuli ei sobinud Astridile lasteaia kollektiivpuhkuse tõttu ning minu meelest Siberi ekspeditsiooniks parimal ajal - juunis - ei saanud sõita, sest riiklike programmide Eesti keel ja rahvuslik mälu ja Setumaa kultuuriprogramm raha polnud aprillis veel laekunud. Piletid tulnuks aga hankida juba siis. Kahjutundega loobusin 6. ja 7. augustil Jõhvis toimuvast konverentsist "Diasporaa roll Eesti iseseisvuse taastamisel". Elus tuleb tihtipeale teha valikuid. Septembrikuu, aga ka näiteks oktoober, ei sobi pakiliste sügistööde tõttu - kõik vähegi töövõimelised inimesed on ametis põllul.

Küsitleda püüdsime võimalikult mitmekülgselt. Enim infot saime külade asustusloo, laulutraditsiooni, rahvakalendri kombestiku, peretähtpäevade, rah-
\end{abstract}


vapäraste ravivõtete ja -viiside kohta. Fotodena ja videolindile jäädvustasime ka külade kalmistukultuuri, käsitööesemeid, toasisustust, elamuid jms.

Muidugi erines kogutud materjal külati ja isikuti. Haida külas keskendusime lauljate ja jutuvestjate jäädvustamisele, Krestjanskis kogusime rohkem usundilist pärimust, mõnevõrra ka majandusloitse. Uus-Petseri ja Estonia külades talletasime eeskätt olustikulist materjali. Viimastel Siberi ekspeditsioonidel on pärimuse kogumise kõrval olnud meie huviorbiidis ka elanike igapäevaelu: varasem töö ühismajandites, toimetulemine tänapäeval, elamud ja nende sisustus, toitumistavad jne.

Välitöö tulemusena kogusime umbes 75 tundi helisalvestusi, 30 tundi videosalvestusi, üle 2000 foto, lisaks kogujate välitööpäevikud.

$$
* * *
$$

Krasnojarskis maabusime kohaliku aja järgi varahommikul. Ajavahe Moskvaga on neli tundi, Eestiga tervelt viis. Öö jäi sedakorda peaaegu vahele ja ajavahe mõjutas mõnda aega ka meie töövõimet.

Kuni pagasi kätte saime ja bussisappa asusime, oli Krasnojarskisse suunduv buss puupüsti rahvast täis ja meil tuli oma kompsudega jääda ootama teist. Varahommikul oli sooja vaid 12 kraadi - säh sulle suvist sooja Siberit! Hiljem selgus, et ilmad ongi tänavu Siberis jahedavõitu ja vihmased ning külaelanikel heinatööga tükk tegemist.

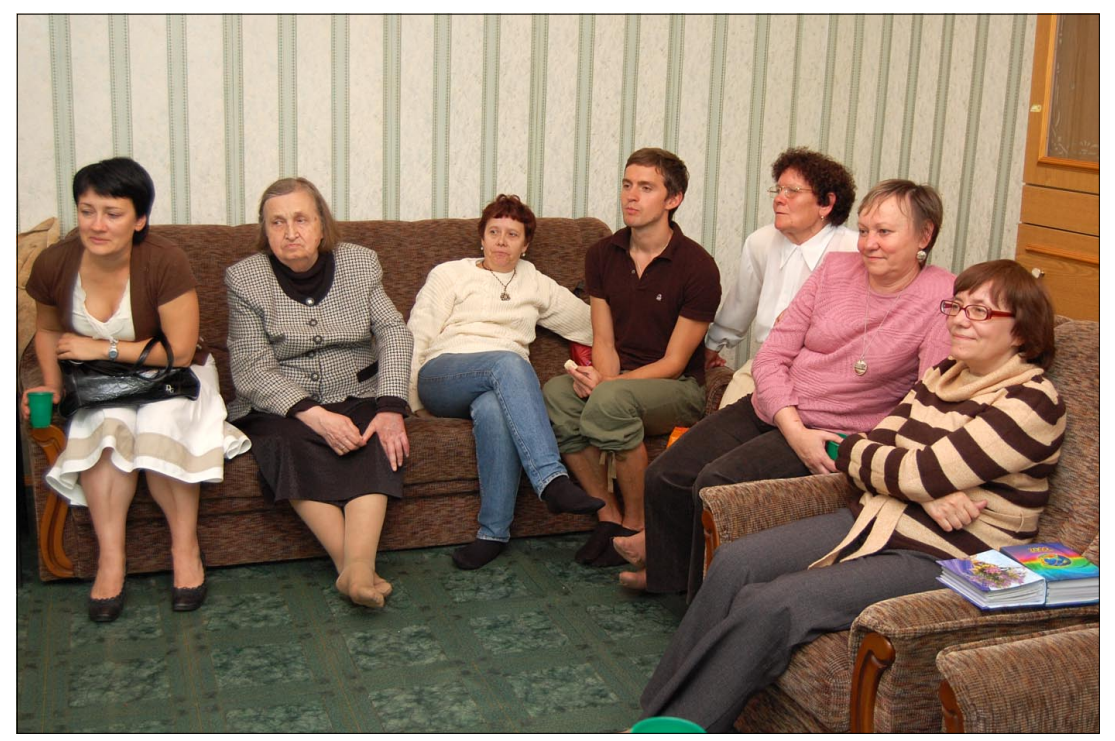

Foto 1. Krasnojarski Eesti Seltsi liikmed ja Andreas Kalkun (keskel). Tiit Sibula foto 2008. 
Mõõduka hinnaga, peaaegu kesklinnas asuvas võõrastemajas Гостиный двор saab ka viisa registreerida - viimane toiming on Venemaal välismaalastele kohustuslik.

Krasnojarski Eesti Seltsi esimees Vera Nikolajeva on kutsunud seltsi liikmed riiklikku teadusraamatukokku meiega kohtuma. Raamatukogust on viimastel aastatel kujunenud seltsi ürituste läbiviimise paik, kus võetakse arvele ka seltsile kingitud raamatud. Nii saavad kõik soovijad neid kasutada. Kohtumisele on tulnud mullusest tuttavad Ludmilla (Ljusja) Andrejeva, Aleksander (Saša) Lukin, Helvi Kuus, Linda Lillart, Valentina Nikitina jt. Tutvustame mullusuvise kogumistöö tulemusi, demonstreerides kaasavõetud DVDdelt ja CDdelt Haida naiste laule-tantse. Koopiad kogutust kingime seltsile, nagu ka raamatuid ja ajalehti. Mõne eestlasega kohtume hiljemgi, näiteks Ülem-Bulankast pärit Liina Kravtsovaga tema töökohal raudtee piirkonnas asuva kaubamaja juveeliletis. Liina eesti keel on muide ladus ja aktsenditu.

Plaanisime alustada läbikäimata küladest, kuid meid Andrease ja Margega mullu majutanud ja meie eest igati hoolitsenud Galina ja Anatoli Jevsejev on seltsi esimehelt meie tulekust kuulnud ja valmistunud vastuvõtuks. Seega alustame tuttavatest paikadest Bulatnovkast (elanikke umbes 20) ja Haidakist (elanikke umbes 190), kust kavatseme suunduda mullu külastatud Krestjanskisse (elanikke umbes 70).

Pärast kolme-neljatunnist bussisõitu oleme Zapadnõi Imbežis, kust Galja sõidutab meid oma koju Bulatnovka külakeses. Meile on köetud saun ja voodidki valmis tehtud. Astrid ja mina saame oma käsutusse tagatoa, mehed veranda.

Galja Jevsejev on kuidagi muutunud ja endassetõmbunud - elurõõmu kaotanud. Kas vaevavad teda terviseprobleemid, ähvardav töökohakaotus või veel midagi mulle teadmatut, jääb saladuseks, kuid eelmisel aastal õhinaga meie tööle kaasa elavast Galjast pole suurt midagi järel. Ka jääb tänavu ära Seto Kuningriigi päeva tähistamine. Tunnen end veidi süüdlasena, et jälle Galja hoole all oleme ja sellega talle kohustusi lisame, kuid muud lahendust ei leia.

$$
* * *
$$

Teist korda samadesse küladesse tagasi tulla on ütlemata mõnus, sest kõik kohtlevad meid kui vanu tuttavaid. Olen lubadust pidades saatnud vahepeal küladesse mullu tehtud fotod ja mõned helikassetid. Nüüd on meil kaasas rahvuskaaslaste programmi rahalisel toel valmistatud DVDd ja CDd Haida, Bulatnovka ja Krestjanski naiste laulude-juttudega ning Andreasel kümmekond eksemplari Peko Helü numbrit, kus on avaldatud tema värvifotodega rohkelt illustreeritud artikkel Siberi setudest. 
Kito Nastat enam küsitleda ei saa, sest tema laulab nüüd taevases kooris. Sellest on küll tuline kahju. Käime tema haual Haida surnuaial.

Kalmistu on rohtu kasvanud nagu mullugi, vaid mõnelt platsilt on hiljuti rohi niidetud, näiteks Jevsejevi siniseks värvitud lippaiaga ümbritsetud perekonnaplatsilt, kus on suur laud ja istepingid, kõik vakstuga kaetud. Nii puulippidest kui ka massiivsest rauast aiaga ümbritsetud perekonnaplatsidel valitseb hauatähiste osas valitseb mitmekesisus ja kirevus: tavalised luterlaste puuristid, õigeusklike ristid, katusega puuristid, erinevad mälestusmärgidpaamjatnikud jne. Iseloomulik on portreefoto hauatähisel. Kito Nasta, Ossipova Manni ema valatud hauaplatsil on uhke paamjatnik ja rohkesti kunstlilli. Andreas asetab kääpa jalamile omakorjatud kalkarijuureq - punaste nuppudega taimed.

Laulikute lindistamine on üks meie eesmärke. Külastame järgemööda laulunaisi Aliidia Kondratjevat ehk Maksi Liidet, Maria (Manni) Petersoni ja Maria (Manni) Ossipovat, et veidi juttu ajada, DVDd üle anda ja naisi uuesti laulma kutsuda, et laule veel kord paremate seadmetega jäädvustada. Käime ka suurlauliku Semmeni Olli ehk Olga Matvejeva pool, kes mullu laulis osalt üksi, osalt koos Kopa Manni ehk Maria Vassiljevaga. Hiljem selgub, et Olga asunud plaati innukalt kuulama, unustanud söögigi pliidile ja selle põhja kõrvetanud. Meid uuesti kohates palub Olli: "Saatke mulle veel neid kettaid!"

Kopa Manni kohta arvab külarahvas, et ta haiguse tõttu vaevalt enam laulda jõuab. Manni kurdabki, et tõbi läts noorembas, esi vanembas, kuid laulab Olliga koos siiski mõned laulud, ehkki peab kõnelemisel-laulmisel vahet pidama ning osalt räägib meiega pool-lamaskil. Lõpuks tuleb ta kogu jõudu kokku võttes meid ukseni saatma ja mul on hea meel, et tema poole sisse astusime.

Tundub, et peaaegu kõigil vanematel inimestel külas on lapselapsi hoida. Siin kehtib veel põhimõte, et linnalapsed tulevad suveks maale vanaema juurde. Enamik linnas elavatest lapselastest setu keelt ei oska. Liide märgib tütrelastele osutades: Nuuq omma vindlaseq, Liide lapsed aga saavad emakeelega ilusti hakkama. Petersoni Manni täheldab ühiskonnas toimunud muutuste mõju elanike eneseteadvusele, oma juurte otsingut: lat'se kirotati russkie, aga nüüd om jälki seto jago.

Täheldatav on mõningane järjepidevus lauluoskuse edasiandmisel. Üks Manni lapselastest - Igor Peterson, dikteerib üsna soravalt laulu "Kikas ütel 
kanale..." Galina Jevsejeva kutsub esinema 2005. aastal loodud Haida laste folklooriansambli Kullõrkukk (vene k Куллэрь Кук). Kultuurimajja saabub kaheksast lapsest seitse, Leena Mamedova on vanematega kuhugi ära sõitnud. Meile laulavad Paša Nikitin, Daša Jefimova, Liisa Otti, Daša Peterson, Maša Zemurbeis, Katja Nagibina, Vanja Zemurbeis. Maša ja Vanja on muide suurlauliku Semmeni Olli lapselapsed, ja ansambli koosseisu kuulub ka Petersoni Manni järeltulija.

Lapsi õpetavat põhiliselt Liide Leedo, kellele aga lastega külast väljaspool esinemas käimine ei meeldivat ja nii tuleb Galina Jevsejeval see enda peale võtta. Galja taotletud Krasnojarski krai grandiprojekti abil on soetatud lastele esinemisriided. Liide Leedol jutuajamiseks aega ei leidu, ta ei tule ka laste esinemist vaatama. Kaheksa lauluga - kaks viimast koos tantsuga - kava on perfektselt selgeks õpitud ja eelnevat harjutamist tegelikult ei vaja. Enne salvestamist siiski tehakse proovi. Jäädvustame elamusliku ja hoogsa esinemise rahvaluulearhiivi jaoks nii helis kui ka videos.

$$
* * *
$$

Laulunaised kogunevad klubisse laulma 7. augusti õhtul, kui loomad on talitatud ja lapsed söödetud. Kokkutulemiseks valitakse annepäev, sest klubijuhataja on Anna, setupäraselt Anne, vene moodi Anja. Naised teavad ka minu nime. Et setud on õigeusklikud, tähistatakse annepäeva õigeusu kalendri järgi. Õigupoolest pole see külas üldine pidupäev, kuid vahel on seda siiski väikest viisi tähistatud. Saame Annaga mõlemad kireva lillebuketi. Tähelepanuavaldus on muidugi meeldiv. Olen Eestiski mõelnud loobuda oma hilissügisese sünnipäeva pidamisest ja asendada see suvise nimepäeva tähistamisega, kuid mõtteks on see seni jäänudki.

Nagu mullugi, on klubi kõrvalruumi kaetud laud, kuhu naised on igaüks midagi kodunt loonud: pirukaid, täidetud mune, võileibu, salatit, komme-küpsiseid, muidugi ei puudu ka napsipudel. Meie lisame omalt poolt "Vana Tallinna” ja Eestimaa komme.

Kohal on kõik mullused laulunaised: Anna, Tanja, Liide ning kaks Mannit, lisaks neile tänavu ka Semmeni Olli, kes kõigi naistega nähtavasti hästi ei sobi, kuid oskab kõikidest paremini just vanu laule. Et ta elab klubijuhataja Annaga ühes majas, arvan, et just Anna võis Ollit laulma meelitada. Ehk on oma osa siin ka meil ja Ollile toodud CD-l.

Annepäeva õhtuse lindistamise jooksul lauldakse kõike: nii vanu kui uuemaid setu, eesti ja vene laule. Laulikutel on erinev repertuaar ja maitse. Vene laule Olli enamasti kaasa ei laula, vanemaid regivärsilisi laule ei tunne jälle nooremad naised Tanja ja Anna. Vastu kauplevad naised Andreaselt ja Tiidult üsna mitu laulu. Kes mõistab, laulab kaasa. Mõnusalt meeleolukalt ja spon- 


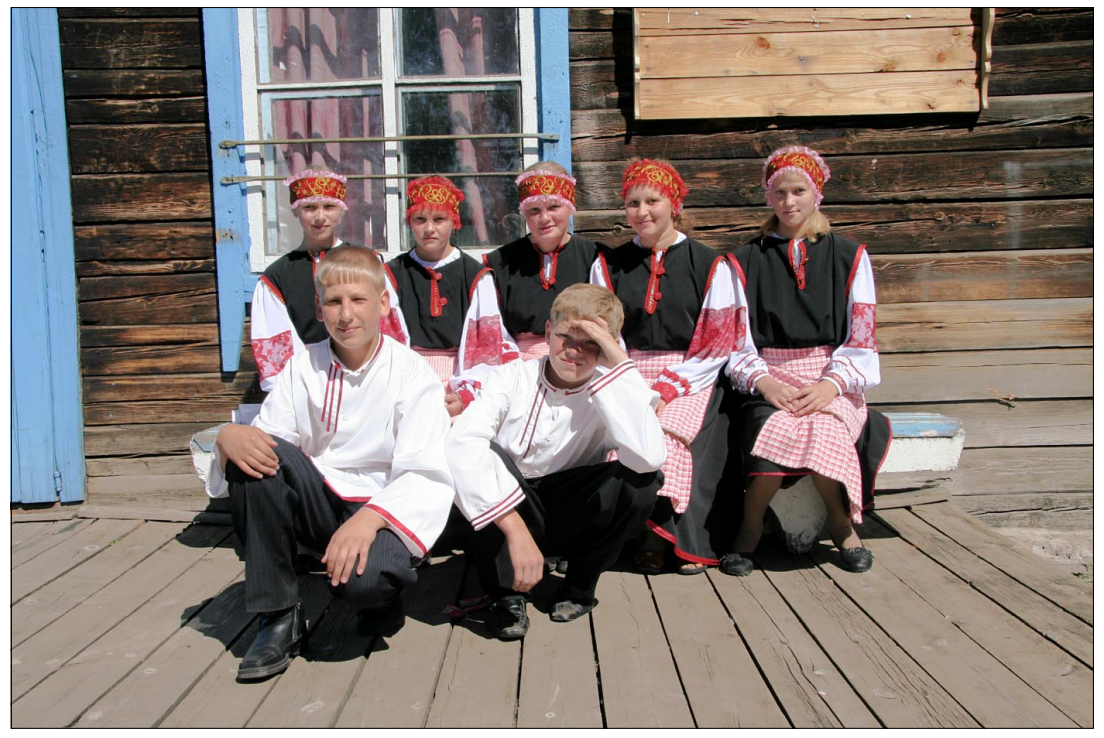

Foto 2. Haida küla laste folklooriansambel Kullõrkukk. Andreas Kalkuni foto 2008.

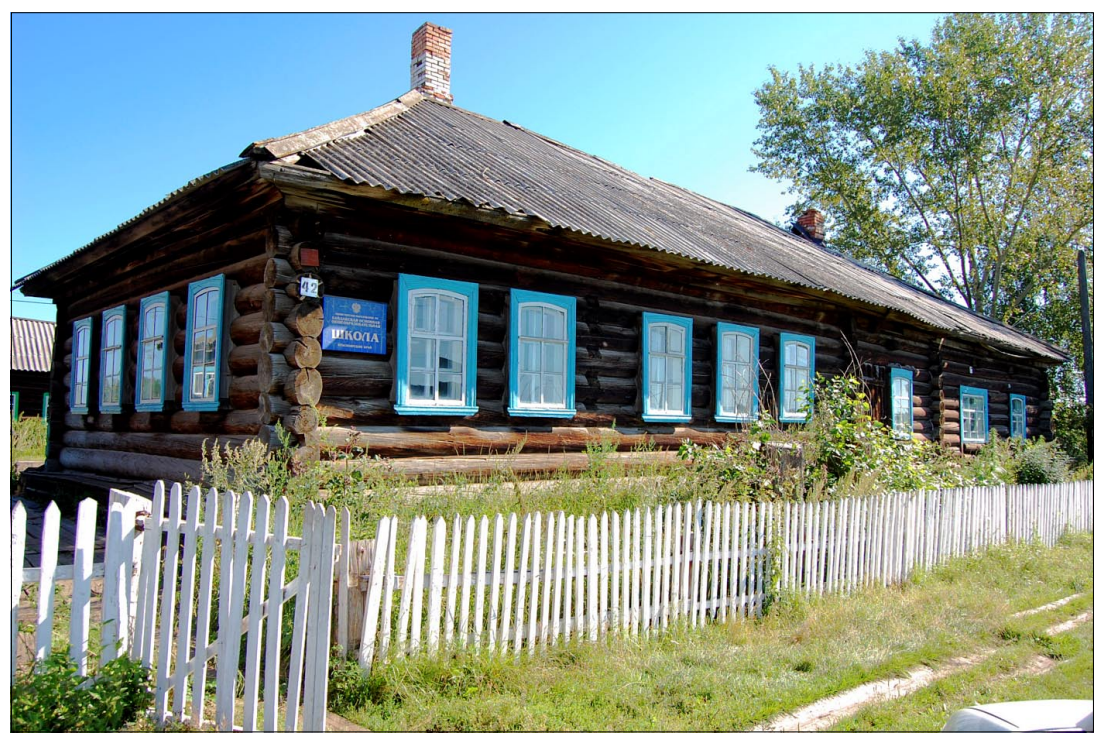

Foto 3. Haida koolimaja.

Tiit Sibula foto 2008. 
taanselt õhtult keegi koju ei kipu. Mõnegi laulunaise lapselapsed piiluvad lõpuks ukse vahelt, et kuhu see vanaema nii kauaks jääb. Koju minnakse kaugelt pärast südaööd, kui meile järele tulnud Anatoli viib laulunaised koju. Andreas sõidab naisi saatma, koos lauldakse nii autos kui veel värava tagagi. Kõigil on kahju lõpetada.

Mõtlemapanev on külaskäik 2001. aastal Haida kooli juurde rajatud muuseumisse. Aeg eksponaatide vaatamiseks pole just kõige parem, sest koolimajas on igasuvise remondi tõttu asju ringi tõstetud ning koristamata ruumis on üksjagu tolmu. Nii et õiget pilti muuseumist ei saa. Laste arvu vähenemise tõttu ähvardab kooli aasta pärast sulgemine. Koolihoone saatus on teadmata. Kaalutud on hoone andmist muuseumi käsutusse, kuid pole selge, kes rahastaks selle käigushoidmist. Abi lubanud Vene suursaadik Moskvas Marina Kaljulaid on ametist lahkunud ja muuseumi tulevik esialgu tume.

Saame muuseumis infot Krasnojarski krai riiklike grantide võiduprojekti "Siberi setud. Vana kultuuripärandi taassünd. Haida küla elanike fotod” "“Сиирские сету. Возрождение древней культуры. Фотографическая перепись жителей д. Хайдак") kohta. G. Jevsejeva tehtud fotosid esitleti 2005. aasta 20. augustil. Külaklubist rändas näitus hiljem Krasnojarski endisesse Lenini muuseumi. Aastatel 2005-2006 filmis Galja külaelanikelt vene keeles tulevaste põlvede tarvis jutustusi esivanematest, tööst, pereelust jm.

Jääme Astridiga päevaks Bulatnovkasse mõnda siinset jutustajat uuesti küsitlema. Anne ehk Anna Stepanova kutsub meid lahkesti oma ruumikale verandale ja jätab sinna vähekeseks istuma, et vanad töödressid paremate riiete vastu välja vahetada ja kaugeid külalisi korralikult kostitada: lauale ilmub värske omakasvatatud tomat, laste valmistatud letšo, suitsuliha ja pudel omatehtud samakat. Naadi ehk Nadežda Kaup saabub Anne poole salvestama ja naistel jätkub juttu peaaegu õhtuni, veidikeseks liitub pensionitooja Valentina (Valja) Mihhailova. Jutustatakse nii endisaegsetest kui ka tänapäeva kommetest, rahvaravitsejaist, haigustest jm.

Krestjanskis küsitlemiseks varume kaks päeva. Mullusest on mul meeles, et kell 11.30 väljuva bussiga sai Krestjanski teeotsa. Jääme ootama. Et bussi ei tule ega tule ja keegi bussist midagi ei tea, võtame takso. Vahepeal on siia tekkinud ametlik taksofirma, saame Krestjanskisse 100 rublaga. 


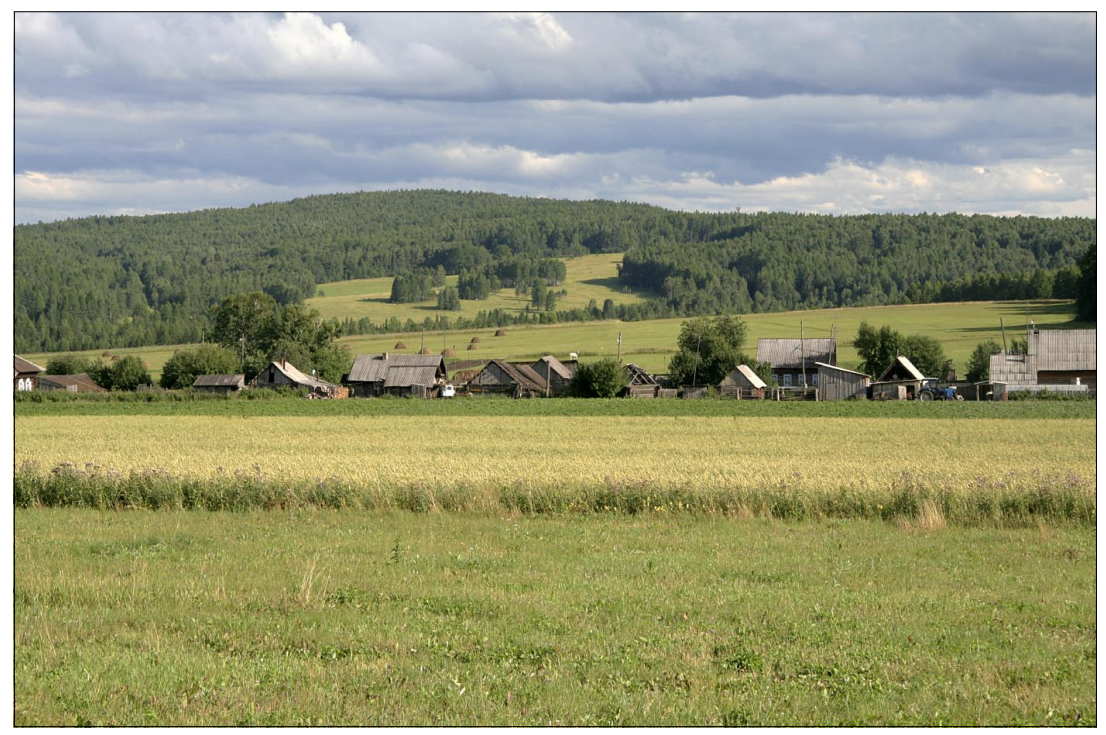

Foto 4. Vaade Bulatnovka külale. Andreas Kalkuni foto 2008.

Külas on elu mõnevõrra edenenud: siia on tekkinud väike erapoeke. Kohalikele see meeldib, mullu tuli ju iga väikseimagi asja pärast sõita rajoonikeskusse. Kui autot pole, on 7-8 kilomeetrit üksjagu pikk maa.

Esmalt käime külavanema Veera Jeremejeva juures oma tulekust teatamas. Veera tunneb meid kohemaid ära ja võtab lahkesti vastu. Saame ka huvitavat teavet - oleme tahtmatult eksinud kirjutamata reeglite vastu: mullu tehtud fotode kättesaamisel tundnud naised meelespidamise üle head meelt, kuid probleemiks osutunud Andrease foto, kus naised paljajalu. Jekaterina (Kati) Horovetsi toas laulmisel olid nad tavakohaselt jätnud kingad ukse taha. Pildistamisel arvanud aga, et ega jalgu pildistata. Jätke meelde, pärimusekogujad, kes te oma vestluskaaslastest fotosid teete! Sama, muidu päris ilus pilt, vaatab kõigile kahjuks vastu ka Peko Helü numbris.

Minul on Krestjanski naistele CD nende lauludega. Et see on must materjal, kust ei ole segiminekuid välja võetud, kahtlustan, et ka laulude kuulamine võib põhjustada siin üksjagu probleeme.

V. Jeremejeva lõpetab meie saabudes parajasti rosinatega pannkookide küpsetamist, pakub meile lahkesti õuepingil istet ja läheb külaliste tarvis tuba korda seadma, seejärel riideid vahetama. Süüa pakub ta meile oma tibatillukeses tare kõrval asuvas suveköögis: maitsev supp ja pannkoogid. Kardame, et sööme külaliste eest kõik ära, kuid toitu on tehtud palju, jätkub kõigile.

Pärime mullu augustis tähistatud küla 100. aastapäeva kohta: ilm olevat olnud väga vihmane ja nii saadud pidutseda vaid vanas klubihoones. Peale 
külas sündinud-kasvanud inimeste olnud kohal ka naaberkülade rahvast ja rajoonikeskuse ametnikud, viimased toetanud üritust aineliselt.

Järgmine küsitletav Maria (Manni) Jeremejeva on kahtlemata üks parimaid pärimusetundjaid, keda iial kohanud olen. Naine asub üsna kergesti jutustama ning teab rääkida peaaegu kõigest, mida üldse küsida oskame. Õnneks sedakorda keegi külla ei tule (mullu katkestati meie jutuajamisi korduvalt) ja me saame rahumeeli salvestada. Kahjuks istub Manni lauast eemal diivanil, hoian salvestajat esmalt lauanurgal ja seejärel Mannile lähemal taburetil. Kumbki paik pole päris hea, pealegi müriseb samas nurgas ka külmkapp, õnneks mitte eriti häälekalt. Veedame Manni pool veel järgmiselgi päeval hulk aega ja jutust puudu ei tule. Naisel on korjatud hulga tsaihainu ja keldris ka pikä-viin, mille meile näitamiseks korraks välja toob. Muidugi kostitab Manni meid mõlemal päeval, pakub ka punast poeviina, ning paneb kaasa keedetud mune ja värskeid kurke.

Anne Haavapuu juurde jäi mullu visiit liiga lühikeseks, seekord ajame tükk aega juttu. Anne teab vanast ajast ja kommetest rääkida rohkemgi, kui oleksime osanud oodata, teab ka, et tema esivanemad pärinevad Unkavitsa ja Puravitsa külast.

Külastame põgusalt ka Katit (Jekaterina Horovets), kelle juurde naised mullu laulma kogunesid. Kati asub meid omakorda kostitama. Pakutud piparmünditee ehk mjaata-tsai on väga hea ja oma aiast korjatud vaarikad samuti. Oleme aga Anne juures ülimalt täissöönud. Lõpuks ulatab Kati mulle 1,5-liitrise plastikpudeli väga magusa vaarika toormoosiga, mis kulub meile järgmises ööbimiskohas marjaks ära.

Vahepeal käime küsitlemas Mana rajoonis Kijai ja Ostrovki külas, kuhu mullu ei jõudnud. Teame, et Kijai polnud algselt setu küla, vaid nad on siia elama asunud muudest küladest, mistõttu on huvitav jälgida päritolu küsimusi. Küla on mitme uulitsaga, on sidejaoskond, võrdlemisi suur koolimaja ja kolm poodi. Ühtki kontakti meil eelnevalt pole. Eestlaste ja/või setude järele pärides saame teada üsna mitu nime. Saame jutule Tsentralnaja uulitsas elava Sinaida Kirillovaga. Hoovivärav on lukus - väravate lukustamine tundub olevat siin kombeks ja küllap on selleks oma põhjus -, kinnised sisehoovid on enamjaolt laudpõrandatega. Siina käimine on haigete jalgade tõttu vaevaline. Jutleme kitsukesel verandal, kuhu kostab tänavamüra. Ta on lahkesti nõus meid majutama. Magame kõik ühes toas ja meie Astridiga jagame kitsukest voodit.

Siina Kirillova vanaema olevat tulnud Eestimaalt, ise on ta sündinud Vassiljevka küla lähistel, sealt olevat siirdutud 1940. aastal Koolupi külla, kus olevat olnud tol ajal umbes 70 talu. Koolupi lagunemise järel olevat tulnud naine 
koos paljude teiste sealsete setudega Kijaisse. Jutuajamise kestel põikab Siina - muide siin kutsutakse teda millegipärast Okse, Kirila Okse - poole sisse ka Maria (Maša) Gavrilova, kes on sündinud Serednä Maani huutoris ja jõudnud sealt Koolupi kaudu oma praegusse elupaika. Jutukam ja sõnakam Maša võtab vestluse juhtimise suuresti enda peale.

Küsitleme veel Alla Haavapuud, Krestjanskis elava Anne Haavapuu velenaast, kes tulnud siia samuti Koolupist. Alla eestlasest mees kõnelenud ka setu keelt, ta ise tellinud omal ajal Eestimaalt ajalehtigi.

61-aastane Valja Prudiust peab pensionipõlve, varem on naine töötanud nii poes kui ka majandis raamatupidajana. Nüüd elab riigi majas ega taha meid kutsuda oma vaesevõitu lagunema kippuvasse elamisse, vaid sätib hoopis katkisele õuepingile teki ja palub meil istuda. Meiega suhtleb Valja vene keeles, sest arvab, et ei oska eesti keelt piisavalt. Sündinud valgevene külas Akilovkas, eestlasest ema ja valgevenelasest isa peres on ta hiljem elanud Koolupis ja sealtkaudu jõunud Kijaisse. Et ta ei oska nimetada esivanemate sünni- või elupaika Eestis ega mäleta nende nimesid on peaaegu võimatu aidata tal esivanematest rohkem teada saada. Valjal on poeg ja tütar. Poeg tahtnud esmalt Kijaisse perele maja ehitada, kuid majandite lagunemise ajal polnud enam tööd ja nii asutudki perega suurlinna, kus tuleb suur osa teenistusest maksta korteriüüriks.

Valjale meeldib mets ja ta kuurialuses ripuvad ravimtaimed. Naine kingib meilegi kummalegi kimbu punet, mida ise nimetab lesnitšnaja mjaata.

Keeleprobleemide kõrval on takistuseks muulastest elukaaslased ja kurjad koerad. Eesti soost mehe väravast Škol'naja uulitsas ei saa me kurja koera tõttu sisse. Helistamise peale tuleb välja mehe venelannast naine, kes võtab eestlastest kuuldes otsekohe sõjaka hoiaku ja lubab meile miilitsa kaela saata, kui me kohe ei lahku. Värava taha koguneb üksjagu uudistavat publikut. Kuigi teejuhina kaasa tulnud Valja püüab meid kaitsta, ei vaibu naise sõjakus karvavõrdki. Tema argument on, et meile ei või midagi rääkida, pärast kirjutavad veel ajalehes... Tundub, et kära peale välja ilmunud mees räägiks küll ja emakeelt valdab ta ka, kuid me peame paremaks naise sõjakuse ees taanduda. Ka Evald Kägo venelannast naine ei taha lubada oma meest võõrastega juttu ajama, pealegi veel talle võõras keeles.

Käime veidi külast väljas mäerünkal asuval surnuaial, mis on ümbritsetud lippaiaga. Setude kalmusid on nende vene nimede tõttu peaaegu võimatu leida, kuid mõned vene keelereeglite järgi moondunud eesti nimed jäävad silma: Haavapuu (Хавабу), Sikk (Сик), Teder (Тетер), Vahter. Viimase hauatähis meenutab Eestimaist, võimalik, et ongi Eestist toodud. 
Ostrovki poole liigume jalgsi, lootes peatada mõni masin, kuid see pole suurel maanteel eriti lihtne. Seega matkame jalgsi üle 10 kilomeetri, põgusa vahepeatusega heinakuhjas.

Ostrovki osutub üsna pisikeseks ühe uulitsaga külakeseks, kus eestlasi on järel vaid kaks, Praskovja ehk Patsi Loskova ning Maria Luugus - üks ühes, teine teises külaotsas.

Patsi juurde pääseme naabri abil, kes suleb koera kuudiava raudplaadiga, et me mööda pääseksime. Mees tuleb hiljem kontrollima, kas kõik on ikka korras, ega tegu ole ebasoovitavate hulgustega. Nii et naabrivalve siin toimib. Naise jalad on kevadest saati väga haiged ja paistes nagu puupakud. Mullu, kui tervis parem olnud, käinud Patsi veel Haidas kostman. Naine mäletab ka Mare Piho külastust, kuid on küsitlemiseks kahjuks liiga vana ja viletsa tervisega.

Maria Luugus tuleb meiega juttu ajama tänavaäärsele pingile. Naine on üsna jutukas, kuid koht pole pikemaks küsitlemiseks kõige parem: mööda sõidavad masinad, hauguvad külakoerad, pealegi tuleb ka ületee-naaber meid uudistama. Lõpuks hangib ta meile Bulatnovkasse sõitmiseks transpordi meie sõidutajaks saab kohalik lätlannast ema ja ukrainlasest isa peres kasvanud noormees.

Eestlastega seoses meenutatakse sõja ajal Haida külas elanud kodueestlasi ja räägitakse siitkandi mehe Endel Puusepa Eestis venekeelsena välja antud raamatust Тревожное небо.

Rõbinski rajoonis asuvasse Uus-Petserisse (Новая Печора) sõiduga läheb üksjagu aega, sest otseühendust pole. Sõidame Partisanskist bussiga Ujari, kolmetunnise ootamise järel rongiga Zaozjornõisse. Paraku on lõunane buss just väljunud ja meil tuleb kas oodata õhtuni või võtta takso. Pika arupidamise järel otsustame viimase kasuks.

Uus-Petseri külas on praegu umbes 250 elanikku, varem elanud küla ühes pooles eestlased, teises setud, aedki olnud vahel. Ka kalmistul olnud eesti ja setu jagu. Hauaplaatidelt leiame üksjagu eesti nimesid: Liiv, Prost, Lillo, Linask jt. Uus-Petseris olevat olnud suur seafarm ning külas elatud päris jõukalt. Nüüdseks on majandid lagunenud ja tööd eriti pole.

Külas on ka raamatukogu ja siin sündinud venelannast raamatukoguhoidja Larissa Pronjakova näib üsna entusiastlik. Lugejaid olevat lausa 200, seda muidugi ka suveks külla tulnud laste arvelt. Hiljuti saadud väikestele raama- 
tukogudele tehnika ostmiseks mõeldud piirkondliku grandi abiga loodetakse soetada arvuti ning heli- ja videotehnika. Raamatukogu juures töötab mesindusring ja kaks käsitööringi, elanikelt on kogutud külaajalugu. Eestikeelseid raamatuid siin ei ole, millegipärast puuduvad ka eesti autorite vene keeles ilmunud teosed, mida külarahvas tegelikult lugeda tahaks.

Enamik keskealisi, vanemaist rääkimata, oskab siin üsna ladusalt lõunaeesti või setu murdekeelt. Üks vene naine väidab, et tema tütrele meeldinud eesti keel niivõrd, et ta olevat selle ära õppinud, samas mõned keelt valdavad eestlased siiski emakeeles suhelda ei taha. Huvitavat ainestikku saame Pavel (Paul) Bogdanovi, Liida (Liide) Antonova, Matilda ja Pjotr Pavlovi käest. Matilda, tüdrukupõlves Raud, on olnud mitu korda abielus. Praegune perekonnanimi on tal juba neljas. Passi järgi olevat naise eesnimi nüüd hoopis Zinaida, nime vahetanud ta mehe pärast - tollele polevat Matilda meeldinud.

Pjotr Pavlov on olnud kahe-klassilisest haridusest hoolimata nii brigadir kui kolhoosiesimees. Mees märgib, et praegune 6000 rubla suurune pension jääb ostujõu poolest kaugelt alla omaaegsele 120 rublale. Keegi ettevõtlik mees on üritanud külas tootmist arendada ja on parasjagu eeluurimise all. Osa külaelanikest usub tema süüd, osa leiab, et meest süüdistatakse asjata ja töötavad inimesed pole Venemaale vajalikud. Külamees Valter Liivi sõnutsi elavatki venelased rahulolus, et täna on leiba, kas homme ka on, sellele ei mõelda.

Elsa Deminale (neiuna Vilde) on meie saabumine veidi ootamatu, kuid ta kogub end kiiresti ja majutab meid tütremehe suvilas. See on väike majake: veranda, köök, tuba ning hiljem juurde ehitatud saun ja suveköök. Suhteliselt väikeses toakeses on võrdlemisi mugav.

Elsa elab ise Krasnojarskis ja vaid suvitab siin. Tema hoole all on ka tütrelapsed. Elsa onu, ema vend, olnud kauaaegne Uus-Petseri kooli direktor. Nüüdseks on kool kinni pandud ja lapsed õpivad naaberkülas Aleksandrovkas, kus asub ka külanõukogu. Elsa tütrepoeg Dimitri Jakovlev aga õpib rahvuskaaslaste programmi toel Tartu Ülikoolis.

Vene vägedest Gruusias kuuleme esmakordselt Eestist saadud SMSi vahendusel, sündmus mõjutab meid hiljem otseselt - päevakorral on nn terrorioht. Uus-Petseri küla asub nimelt mõne kilomeetri kaugusel kinnisest linnast Zelenogorskist, varasema nimetusega Krasnojarsk-45. Linna tekkides kadusid mitmed setude asualad. Külanõukogu esimeest kohtame poes ja ta pöördub meie poole küsimusega: Кто старший? Venelastel on hierarhiasüsteem kindlalt paigas ja keegi peab ilmtingimata olema juht. Mees mainib, et lähedal asub jadernaja zona ja pärib meie visiidi eesmärgi kohta. Seletan talle pikalt-laialt, et oleme folkloristid ja tahame oma rahvuskaaslaste elust rohkem teada. Ar- 
van, et sellega kõik piirdub. Paraku eksin. Kui küla vana pillimehe Pavel Bogdanoviga juttu puhume, kostab nõudlik kellahelin ja värava taga on vormis mehed. Kaks meest ütlevad end olevat terrorismi vastu võitlemise rühmast, tahavad näha dokumente ja nõuavad selgitust, miks me külas oleme, kelle juures peatume, millal lahkume jne. Pannakse kirja kõigi isikuandmed ja selgitus, miks me tulime. Sama tehakse meid võõrustanud Elsa Deminaga. Sellest jääb veel väheks: meid pildistatakse nagu kurjategijaid nii eest- kui ka külgvaates. Minul on üks silm lootusetult paistes, sest sain hommikul otse läbi soo külla minnes moškidelt pureda, nähtavasti oli jadernaja moška! Olukord on üksjagu koomiline, kuid ka alandav. Õnneks võtab Elsa ülekuulamist külma rahuga. Järgmisel päeval on mehed tagasi, vabandavad ette ja taha, sest olevat unustanud teha koopia meie isikuandmetest passis ja viisast. Ametimeeste kahtlustav käik mõjutab suhteid külarahvaga ning sestpeale jäävad vähemalt Andrease ja Tiidu ees uksed enamasti suletuks. Hiljem märkame nii kaupluses kui ka inimeste kodudes üleskutseid teatada ametivõimudele augusti-ja septembrikuus kõigist võõrastest külas, ettekäändeks võimalik terrorioht piirkonnas.

Nižni Ingaši rajooni Estonia külla on päris pikk maa ja mitme ümberistumisega tülikas sõit: pika ootamise järel Zaozjornajast rongiga Ilanskisse, sealt bussiga rajoonikeskusse ning järgmise bussiga Estoniasse. Ilmad on suve kohta harjumatult külmad.

Umbes 150 elanikuga külake näib üsna räämas ja armetu, rida tühjaks jäänud lagunevaid peremeheta majakesi. Porised külavaheteed võimendavad nukrat pilti. Ja keset seda kõike märkan uulitsat nimega Таллиннская, täpselt niisuguses kirjapildis.

Eelnevalt on teada üks nimi - Pauliine Kübart. Hiljem selgub, et tegelikult kannab naine siiski abiellumisjärgset nime - Kazlova. Lapsed juhatavad meid Pauliine väravasse. Välisukse ees on puukepp ja esmalt me kedagi õues ei näe, ka koera pole näha ega kuulda. Naabri abiga leiame Pauliine toimetamas suveköögis. Naine elab poja Aleksandriga (Saša) kahekambrises majas: tagatoas poja ase, ees välisukse juures Pauliine oma. Öömajale võetakse lahkesti. Meie Astridiga saame asemed lahtivõetavale diivanile, mehed on sunnitud magama külmal põrandal, kasukad külje all.

Toas on uskumatult külm, nii et minagi, kes ma end sugugi külmavareseks ei pea, topin selga kõik kaasas olevad riided ja kahetsen, et jätsin sooja kampsuni koju. Eestoas on suur vene ahi, mida millegipärast ei köeta, vahepeal pannakse sooja saamiseks natukeseks tööle elektripuhur. Ka gaasi-ja elektripliidiga suveköök on külmavõitu. Pauliine kutsub Astridi appi süüa tegema, 
sest tema liikumine on haigete jalgade tõttu üsna vaevaline. Mõnel hommikul teeb Saša meilegi kohvi valmis ja keedab tulisoolast suppi. Siberis süüakse hommikul tugevamini kui Eestis, kuid nii palju soola minu organism igatahes vastu ei võta. Probleeme põhjustab ka Tiidu ja Andrease komme juua kohalikest taimedest teed. Pererahvas ei suuda aru saada, miks nad ometi ei võta laual olevaid paketikuid.

Meie perenaine on mures, et peagi 40-le lähenev poeg pole endale naist leidnud. Kaks poega on tal Eestis.

Siitkandist on pöördutud sõja järel massiliselt tagasi Eestisse ja nii palju emamaalt toodud hauaplaate pole vist ühegi teise küla kalmistul. Eestiski käinud omaküla rahvas koos, peetud kokkutulekuid. Pauliine poeg Evald käinud hiljuti Siberis ning kutsuvat ema ja venda tungivalt Eestimaale. Ehk saab minek ka teoks.

Estonias elatud nõukogude aastail, pärast majandite jalule saamist, päris jõukalt: olnud suur seafarm ja peetud muidki loomi. Tööinimesed olevat saanud head palka. Nüüd pole külas tööd ja valitseb minnalaskmismeeleolu. Ka klubi juhataja Galina Smorodino, kelle isa on eestlane ja ema valgevenelane, väidab, et külas pole noortel midagi peale hakata.

Pauliine juhatab meile enam kui kümmet eesti juurtega inimest, kuid mitmed neist meiega siiski emakeelt ei räägi. Astridiga külastame Linda Linaskit. Tema ja Elsa Liimiga ajame juttu Linda ilusas paljude lillepeenardega õues majaäärsel pingil istudes, sest keset päeva magavad toas Linda lapselaps ja tolle sõbranna. Filmiva Astridi ümber koguneb kohalikest lastest fän-klubi, kes kõik kaamerat uudistavad. Kogu see väravast sisse-välja vooriv kamp segab salvestamist ja lõpuks hakkab ka külm.

Teeme veel ühe või teise külaelanikuga juttu, kuid kõige tõhusam on ammendamatute teadmistega Pauliine küsitlemine. Vahetevahel sekkub jutusse, muidugi vene keeles, tuppa põikav Saša, kuid sellest pole suuremat häda, sest tal on majapidamises toimetamist küllaga. Et intiimsemaid teemasid keeldub Pauliine meestega arutamast (Siberi setudele ei tundunud see probleemiks olevat), saadame mehed vahepeal küla peale. Viimasel õhtul küsitlen Pauliinet suveköögis, kus Astrid praeb õhtuks kartulit-liha, ja ootamatult kuulen temalt libahundimuistendi, millest Pauliine räägib kui oma vanaisaga juhtunust.

$* * *$

Abani rajooni küladesse me seekord ei jõudnud, vaid naaseme Krasnojarskisse. Vera Nikolajeva õhutusel käime Astridiga külas J. Bodganovi tütrel, et tutvuda osakesega surnud isa arhiivist, ülejäänu on Novokamala külas venelannast abikaasa valduses. 
Vera Nikolajeva eestvõtmisel kohtume Krasnojarski linnavalitsuse liikme Rašit Gizzatovitš Rafikoviga, kelle ema ja vend elavad Eestis. Mees on üllatavalt hästi kursis Eesti eluga. Tööpuuduse kohta külades arvab ta, et Krasnojarski krais on tööd küll ja küll, kuid selleks tuleb meestel ametit vahetada ja külast lahkuda. Mis saab nii külaelust ja peredest, sellele mees vastust ei tea.

Levivad kuulujutud, et kõik Krasnojarskist väljuvad lennud on tühistatud. Tegelikult on tegemist finantsraskustes kohaliku lennuliiniga ning sellelegi leitakse enne meie väljalendu lahendus. Meie lendame Aeroflotiga. Hüvasti, Krasnojarsk!

Ekspeditsiooni rahastasid riiklik programm Eesti keel ja rahvuslik mälu (projekt "Rahvakultuur Venemaa eesti asundustes" EKRM04-33), Eesti Rahvuskultuuri Fond, Eesti Kultuurkapital, Eesti Teadusfond (grant SF0030180s08).

\section{Kirjandus}

Korb, Anu 2007. Setu kogukonnad Siberis folkloristi vaatevinklist. Paar sammukest XXIII. Eesti Kirjandusmuuseumi aastaraamat. Tartu: Eesti Kirjandusmuuseumi Teaduskirjastus, lk 363-370.

\section{Summary}

\section{Fieldwork among Estonians living in Krasnoyarsk Krai}

Anu Korb

In the summer of 2008, Estonian folklorists Anu Korb, Astrid Tuisk, Andreas Kalkun, and Tiit Sibul took part in the fieldwork expedition carried out among Estonians living in the villages of Krasnoyarsk Krai, Russia. The team of folklorists collected information about the establishment of the villages, the local song tradition, folk calendar rituals, family holidays, popular methods of treatment in folk medicine, and folk tunes.

Next to the lore material collected on previous expeditions in Siberia, the team recorded material about the everyday life of the people: working on collective and state- 
owned farms, coping in present-day Russia, residential houses and their interior, traditional food, etc. The photographs taken and videos recorded inform about the cemetery tradition in the village, local handicraft, interiors of houses, etc.

The 2008 fieldwork expedition resulted in about 75 hours of audio-recorded material, 30 hours of video-recorded material, over 2,000 photographs and the fieldwork diaries of members of the expedition team. 